Proceedings of

the $34^{\text {th }}$ International Business Information Management Association Conference

(IBIMA)

13-14 November 2019

Madrid, Spain

ISBN: 978-0-9998551-3-3

Vision 2025: Education Excellence and Management of Innovations through Sustainable Economic Competitive Advantage

Editor

Khalid S. Soliman

International Business Information Management Association (IBIMA)

Copyright 2019 


\title{
The Effect of Transformational leadership on Job Satisfaction among Academic Staff
}

\author{
Alaa S. JAMEEL \\ Faculty of Technology Management and Business, Universiti Tun Hussein Onn Malaysia \\ 86400 Batu Pahat, Johor, Malaysia \\ salam.alaa23@gmail.com \\ Abd Rahman Ahmad \\ Faculty of Technology Management and Business, Universiti Tun Hussein Onn Malaysia \\ 86400 Batu Pahat, Johor, Malaysia \\ arahman@uthm.edu.my
}

\begin{abstract}
Transformational leadership (TL) play an important role to improve job satisfaction(JS) among employees. however, most of the previous studies conducted in organizations and health sectors, limited studies conducted in the education sector. The purpose of this study to exam the effect of transformational leadership on job satisfaction among academic staff and enrich the body of knowledge in education sector and particularly in Iraq setting. The study conducted at Cihan university-Erbil, Iraq. However, the study employed a quantitative method by Structured questionnaires to collect the data, 137 valid questionnaires has been analysed by structural equation modelling to exam the effect among TL and JS. The result showed there is a positive significant effect of TL on JS among academic staff. moreover, the Individuals consideration found a highest impact on Job satisfaction than other TL dimensions. universities should pay more attention to TL and improve the leader's characteristics among university leaders to enhance the JS among academics staff.
\end{abstract}

Keywords : leadership, transformational leadership, job satisfaction and academics staff.

\section{Introduction}

Leadership styles play an important role in the attainment of organizational goals and enhance followers performance by job satisfaction, however, leader in this study refer to head of department at university. creating satisfy environment among academic staff will lead to an increase in their productivity at universities, meanwhile, the good working environment would encourage leadership styles contributions to get the success of organizations. leadership styles consider important for job satisfaction, meanwhile, transformational leadership (TL) is one of the leadership styles which can enhance and improve job satisfaction among academic staff at universities because focus on an important part of satisfaction which associate feeling and inspiration factors._Transformational leaders has a strong effect on employees attitudes and behaviours Abelha, Carneiro and Cavazotte, (2018). to get better organization performance the organizations should develop TL in their leaders, however, past literature reported leadership styles are essential in organizations and highly effect on job satisfaction Munir et al.,(2012). the good leader which able to use the recourse and individuals activities to achieve the goals. However, success and failure in an organization highly depend on the quality of leadership. a transformational model is able to negate this issue in organizations. Job satisfaction (JS)essential factor in workplace and when missing it will be lead to undesired results such as increase employees turnover, absenteeism, and occupational illnesses Abelha, Carneiro and Cavazotte, (2018). Leadership important element that ensures leader and subordinates emotional, individual job satisfaction and led significantly to grow an organization Singhry (2018). furthermore, the organizations still suffering to understand how leaders stimulate and motivate the followers for future success. The researchers and scholars paid more attention to leadership styles, especially TL in different countries and sectors in same times studies indicated there are a limited studies has been 
conducted to exam the impact of TL on job satisfaction in education sector, most of the previous studies conducted in Bank sector (Puni, Mohammed and Asamoah, (2018); Dappa, Bhatti and Aljarah, (2019),health sector Ahmad et al., (2013); Alghamdi, Topp and AlYami, (2018), organizations Abelha, Carneiro and Cavazotte, (2018); Singhry, (2018) ; An et al., (2019), and construction industry Hanim et al. (2018). Meanwhile, most of the previous study which exam TL and job satisfaction among academics staff has been conducted in developed countries .there is a lack of study in developing countries Jameel and Ahmed, (2019); Bayram and Dinç, (2015) ; Salau et al., (2018).Iraq considered as one of the developing countries. similar to other private universities, Cihan university is noted to high staff turnover which is related to JS and leadership. Thus, the result of this study could be contributing to clarify the mechanisms that relation between leadership and job satisfaction at Cihan University, Iraq. The aim of this study to exam the impact of transformation leadership on job satisfaction among academics staff at Cihan university-Erbil, Iraq.

The study strives to answer a question.

Does TL improve job satisfaction among academic staff at Cihan university-Erbil, Iraq?

\section{Literature Review}

\section{Job Satisfaction}

Job satisfaction considers as one aspect has been attracted the attention of researchers and organizations. according to Spector (1997) indicated there are thousands of studies related to job satisfaction. Several of these studies have been reported that job satisfaction describes the employee feelings and attitudes about assortment of intrinsic and extrinsic job satisfaction. It indicates how content an employee is with their job in workplace and involve particular aspects of satisfaction which is related to wages, promotion, work environment, supervision and relation with colleagues. Spector (1985) defined job satisfaction as the level of positive or negative emotions or felling toward job. job satisfaction is essential for academics staff to enhance academic performance and students satisfaction at universities. employees will provide huge contribution in their work place if they have good feeling and satisfaction about their job Bayram and Dinç (2015).Job satisfaction refers to the positive feeling of the employee's toward the workplace and how much there degree of satisfaction in organizations Ahmad \& Jameel, (2018); De Nobile, (2017) Meanwhile, High level of satisfaction in the workplace could lead to having low turnovers Chen (2006). According to Alghamdi, Topp and AlYami, (2018) Job satisfaction influenced by several factors derived from individuals characteristics and sociocultural factors. however, create Communication channels with individuals and insertion them in decisionmaking can enhance their job satisfaction in an organization Nobile (2017). Organizations with high employee satisfaction could be more productive and effective Dappa, Bhatti and Aljarah, (2019) ; Eliyana, Ma'arif and Muzakki, (2019).academics staff are the most important assets of the university. Meanwhile, universities to be more successful should pay more attention to staff satisfaction. From the view of expectation discrepancy, job satisfaction is a reaction or perception of the difference between the benefits anticipated and the benefits genuinely earned. In this study, we describe job satisfaction as an effective response of staff to their work, work climate or individuals engaged in their career, including emotions of accomplishment and fulfilment with colleagues, colleagues or salaries.

\section{Leadership}

There are several leadership styles (Transformational, transactional, laissez-faire, Bureaucratic and Democratic, etc ) and each one depend on discrete approach and theories of leadership styles, our study will focus on transformational leadership due transformational model can implement to negate the issue in organization Thamrin (2013), if compare between transformational and transactional leadership will find transformational more effect and contribution on job satisfaction Ahmad et al., (2013) and Bass (1997) reported in the study which conducted among managers in the Austrian branch bank and concludes the managers prefer transformational rather than transactional. According to Abelha, Carneiro and Cavazotte, (2018) leadership could be important for motivating organization staff 
and gather resources to achieve organization objectives. employees when getting a clear vision and good inspiration from their leaders will reflect positively to their performance .moreover, leader will get from employees what is expected from them Munir et al., (2012). Leaders play an important role in determining organizational effectiveness over all the levels. meanwhile, the relationship between the leaders and follower occurs in most organization level and activities in a different structure Altunoğlu, Şahin and Babacan, (2019). According to An et al., (2019) Leaders and followers interaction plays important role to effect on organizations performance and outcomes. however, Leaders have different unique talents and skills meanwhile, the organization needs this talent to chosen structural positions Eliyana, Ma'arif and Muzakki, (2019). Thamrin, (2013) Described the qualified leader which use organization resources by the optimally way to achieve organization objective. the success or failure of the organization or university is dependent on the quality of the leadership.

\section{Transformational Leadership}

According to Bass, (1997) ; Bass et al., (2003) TL assist organizations to engage with unstable environments by stimulating their followers to create the best solutions for problems. TL provides a guide to followers toward the vision and help to interchange between leaders and followers, Bass (1985). According to Burns, (1978), the differences between TL leaders and other leaders styles they are respect and appreciation followers achievement and support them to achieve higher performance. organizations are paying more attention to developing TL inside the organizations due it leads to provide better performance Munir et al., (2012). According to Bass et al.,(2003) TL includes working with followers to obtain high efficiency and artistic solutions for the problems. Bass, (2000) emphasize that TL able to involve the employees to participate in the decision making the process and taking their ideas will lead them to feel they are important in the workplace and motivates them to do well in their organizations. TL leaders focusing on assisting the individual's to get succeed and driven them by share with individual's to get inspired, committed and empowering the individuals to match their goals with the organization's goals Torlak and Kuzey, (2019). TL goes over the idea of rewards or punishments between leaders and subordinates Bass et al., (2003) and focuses on motivation, inspiring and stimulating to get goals or vision done in organizations Burns, (1978); Bass, (1985). TL is comprises four components: Bass, (1985) ; Bass et al., (2003) namely idealized influence, inspirational motivation, intellectual stimulation, and individualized consideration. TL factors could create a low turnover among the employee and increase their satisfaction and productivity for the organization however, could encourage collaboration among leaders and subordinate to achieve the task and change for the better.

\section{Idealized influence (II)}

Idealized influence indicates to obtain respect and trust from followers and tends to share passionately with followers and usually, consider as a lead by example. according to Bass and Avolio, (2004) embodied the manners and behaviour in an admirable way that will lead the followers feeling is positively toward the behaviour of the leader and they will adopt this behaviour in the organizations and group. However, II including two sub-dimensions behavioural and attributed that indicates the leaders behave and how the followers perceived to their leaders. Idealized refers to the sense of mission and values and implement these values in the workplace Munir et al., (2012). II describes to the leaders who have a high moral and ethics Northouse, (2016) , they depend on beliefs and values Antonakis, Avolio and Sivasubramaniam, (2003), therefore, they are trusted and admired Avolio and Bass, (2004).

\section{Inspirational motivation (IM)}

increasing followers' level of consciousness which related to organizations vision, mission and objectives to achieve more than what expected in the workplace Bass and Avolio, (2004). IM refers to leaders way that motivates and inspires followers by informing the followers of the meaning and challenge in work Bass and Riggio, (2005), and elucidate and achieve vision Bass and Avolio, (2004) . Inspirational is the ability of the leader to motivate and inspire the followers in the workplace Munir 
et al., (2012). IM reflect how the followers consider their leader in terms of trust, charisma, and spirit Omar and Hussin, (2013).

\section{Intellectual stimulation (IS)}

encouraging followers to be more creative and interrogation the status quo. however, leaders support employees in solving the problems by new ideas and methods and didn't censure them Bass and Avolio, (2004). IS indicate to leaders motivate the individual's efforts to be more creative and implement new ways of approaching old situations Bass et al., (2003).The best method to let followers completing their job by an efficient and effective way it is depends on how the leaders stimulate and encourage them to get the job done Anjali and Anand, (2015).

\section{Individualized consideration (IC)}

related to how the leaders' showing to subordinates' attention and expectations related to growth and development Bass and Avolio, (2004). IC involves emotional support, a supportive environment, modern learning chances Bass and Riggio, (2005), piece of advice and feedback Bass and Avolio,(1993), realize subordinates are in different desires and needs to help individuals achieve it Bass, (1997). to achieve the growth for each individual the leaders should pay attention to each individual needs to achieve Individualized consideration Munir et al., (2012).

\section{TL and Job satisfaction}

TL plays important role in enhancing and stimulating university leadership (Head of department (HD) and Dean ) to create and implementing knowledge in universities however, there are various factors could influence on job satisfaction, one of these factors transformational leadership. a Successful leadership style is able to contribute and increase employee motivation to achieve the organizational mission and goals. Bass and Avolio (1993) emphasize that job satisfaction one of the elements effect on organizational outcomes. However, according to Bass and Avolio (1993) TL could be more efficacious than laissez-faire leadership which is considered as the least dynamic and TL more efficacious than active management and passive management by exception.TL is a key to enhance and develop a vision and overarching goals for their institutions Locke and Latham, (1990) and TL possible to enhance job satisfaction by different mechanisms Bass, (1985); Bass et al., (2003). According to Alghamdi, Topp and AlYami, (2018) cannot separate Transformational leadership from Job satisfaction and other individual characteristics. Leadership has an obvious impact on job satisfaction Bayram and Dinç, (2015).meanwhile, Transformational leadership leaders are supporting and motivate their employees to achieve human needs as well it is essential to promoting employee satisfaction An et al., (2019). Successful transformational could improve job satisfaction and organizational performance. According to Puni, Mohammed and Asamoah, (2018) still much uncertain about the relationship between Transformational leadership and job satisfaction. however, still not clear the interactive effect and effect size among them. Therefore, various studies reported that Job satisfaction impacted by TL Munir et al., (2012); Ahmad et al., (2013); An et al., (2019); Dappa, Bhatti and Aljarah, (2019); Eliyana, Ma'arif and Muzakki, (2019) , on other hand the result form Thamrin, (2013) found TL cannot increase JS and reported there is a no positive significant influence among tow variables TL and JS, Bayram and Dinç, (2015) found the study conducted in private universities the Individualized consideration and intellectual stimulation did not significantly effect on JS. based on above there is a contrast in results, to clarify the effect of TL on JS in context of private education sector the study will examine the following propose hypothesis.

$H: T L$ has a significant influence on JS. 
Vision 2025: Education Excellence and Management of Innovations through Sustainable Economic Competitive Advantage

\section{Methodology}

The participants in this study were the academic staff at Cihan university-Erbil, Iraq. the study employs quantitative method and used a survey strategy to collect the data by Structured questionnaires. The population of this study 137 valid questionnaires from 200 questionnaires was distributed at university by self-administrative, the questionnaire close-ended questions and used 5-point Likert scales $1=$ strongly agree and $5=$ strongly disagree. this study used Multifactor Leadership Questionnaire (MLQ) to measure transformational dimensions namely Idealized influence (II) 5 items, Inspirational motivation (IM) 5 items, Intellectual stimulation (IS) 5 items, Individualized consideration (IC) 5 items, the total instrument consist of 20 items developed by Bass and Avolio, (2004). these items were used in similar fields by Munir et al., (2012); Torlak and Kuzey, (2019). to measure JS this study consist of 5 items were adapted from Spector, (1985) which is related to salary and promotion. Data collected were analysed by Statistical Package for Social Sciences (SPSS) version 23 to find descriptive statistics ,Cronbach's Alpha and factor loading. However, structural equation modelling SEM, analysis of moment structure (AMOS) version 21 used to measurement model, model fit, model validate and to exam hypothesis path

\section{Data Analysis}

\section{Demographic Descriptive}

In this section the results will starting with demographic characteristics as represented in Table 1 . The majority of the respondents Male with $56.9 \%$ while $43.1 \%$ are Female. The largest responds for this survey was with age group of 40 to $49(40.9 \%)$ and close to this result was with the group of 30 to 39 $(39.4 \%)$ while the young group below 29 years are $2.9 \%$ and above 60 years $1.5 \%$. As expected in Qualifications, most (65.7\%) of the respondents with Master degree while (34.3\%) hold PhDs degree. A large proportion $(61.3 \%)$ of the respondents Assistant Lecturer while $(24.8 \%)$ with Lecturer position, (13\%) Assistant Professor and only one $(0.7 \%)$ belong to Professor.

Table 1: Distribution of socio-demographic data of the respondents.

\begin{tabular}{|c|c|c|c|}
\hline \multicolumn{2}{|c|}{ Variables } & Frequency & Percentage \\
\hline \multirow{3}{*}{ Gender } & Male & 78 & $56.9 \%$ \\
\cline { 2 - 4 } & Female & 59 & $43.1 \%$ \\
\hline \multirow{4}{*}{ Age } & less than 29 & 4 & $2.9 \%$ \\
\cline { 2 - 4 } & 30 to 39 & 54 & $39.4 \%$ \\
\cline { 2 - 4 } & 40 to 49 & 56 & $40.9 \%$ \\
\cline { 2 - 4 } & 50 to 59 & 21 & $15.3 \%$ \\
\cline { 2 - 4 } & above 60 & 2 & $1.5 \%$ \\
\hline \multirow{4}{*}{ Position } & $\begin{array}{c}\text { Assistant } \\
\text { Lecturer }\end{array}$ & 84 & $61.3 \%$ \\
\cline { 2 - 4 } & Lecturer & 34 & $24.8 \%$ \\
\cline { 2 - 4 } & $\begin{array}{c}\text { Assistant } \\
\text { Professor }\end{array}$ & 18 & $13.1 \%$ \\
\cline { 2 - 4 } & Professor & 1 & $0.7 \%$ \\
\hline \multirow{2}{*}{ Qualifications } & Master & 90 & $65.7 \%$ \\
\cline { 2 - 4 } & PhD & 47 & $34.3 \%$ \\
\hline
\end{tabular}




\section{Validity and Reliability}

\section{Convergent validity}

Fornell and Larcker, (1981) Convergent validity can test by first, factors loadings which should be greater than 0.70 and significant. However, according to Hair et al., (2009)factor loadings should be $(\geq .5)$ and high factor loading reflects high convergent. Second, by Average Variance Extracted (AVE), according to Fornell and Larcker, (1981), a high AVE indicate high validity and should be (> .5). table(2) shown factor loadings for TL and JS 0.821,0.812 thus greater than 0.70 threshold. AVE for both constructs are 0.664 and 0.523 greater than 0.50 threshold. results indicated all constructs are achieved the convergent validity.

\section{Reliability}

The reliability of this study tested by Composite Reliability(CR) and Cronbach Alpha, CR to consider reliable should be $>0.70$ Hair et al., (2009). Cronbach Alpha $<.50$ Not reliable, .70 Adequate, .80 Very good and .90 Excellent Kline, (2010). The reliability of this study showed in table (2) CR of TL and JS between 0.850 and 0.869 , which are greater than 0.70. Cronbach Alpha for all constructs between .914 and .850 the results indicated all constructs have a reliable score and achieved and fulfil the rule.

Table 2: validity and reliability

\begin{tabular}{|l|c|c|c|c|c|}
\hline \multicolumn{1}{|c|}{ Construct } & No. Items & AVE $>\mathbf{. 5}$ & $\begin{array}{c}\text { Composite } \\
\text { Reliability } \\
>.7\end{array}$ & $\begin{array}{c}\text { Cronbach's } \\
\text { Alpha }\end{array}$ & $\begin{array}{c}\text { Factor } \\
\text { Lodgings }\end{array}$ \\
\hline JS & 3 & 0.664 & 0.850 & .914 & .821 \\
\hline TL & 8 & 0.523 & 0.869 & .850 & .812 \\
\hline
\end{tabular}

Notes: AVE, averaged variance extracted. TL, Transformational Leadership; JS, Jobs satisfaction.

\section{Measurement Model}

during measurement items by SEM(AMOS) one dimension were dropped from TL (Idealized influence ) due to low factor loading. Likewise, some items were dropped from JS and TL due to the same reason. this smoothly will validation of the model fits. Table (3) clearly describe the model fits of the study . to obtain a model fit should follow the criteria as follows:

according to Byrne, (2001) RMSEA should be less than 0.08 and less than $0.06 \mathrm{Hu}$ and Bentler, (1999),GFI,NFI,CFI should be greater than 0.90 (Chau, 1997), RMR should be less than $0.08 \mathrm{Hu}$ and Bentler, (1999),TLI should be greater than 0.95 Sharma et al., (2005), PCLOSE greater than 0.05 Kline, (2010) and $\chi 2 / \mathrm{df}$ should be less than 5.0 Kline, (2010).

Table 3: Model fits

\begin{tabular}{|c|c|c|c|c|c|c|c|c|}
\hline RMR & GFI & CFI & IFI & TLI & NFI & RMSEA & PCLOSE & $\boldsymbol{\chi} \mathbf{2} /$ df \\
\hline .045192 & .951928 & .977679 & .977820 & .969309 & .961710 & .063731 & .087155 & 2.324081 \\
\hline
\end{tabular}

Notes: $n=137$. CFI, comparative fit index; RMSEA, root mean square error of approximation; GFI = goodnessof-fit index; NFI = normal fit index; $I F I=$ incremental fit index; $T L I=$ Tucker Lewis index; RMR = root-meansquare residual 


\section{Assessment of structural equation model}

Figure 1 represented the structural model of the study and indicates the relationship among TL and JS, table (4) showed that when Transformational Leadership goes up by 1 standard deviation, Job satisfaction goes up by 0.478814 standard deviations. The regression estimate, 0.478814 , has standard error 0.112 . the probability of critical ratio 5.941 in absolute value less than 0.001 , mean the regression for Transformational Leadership prediction of job satisfaction is significantly different from zero at the 0.001 level.

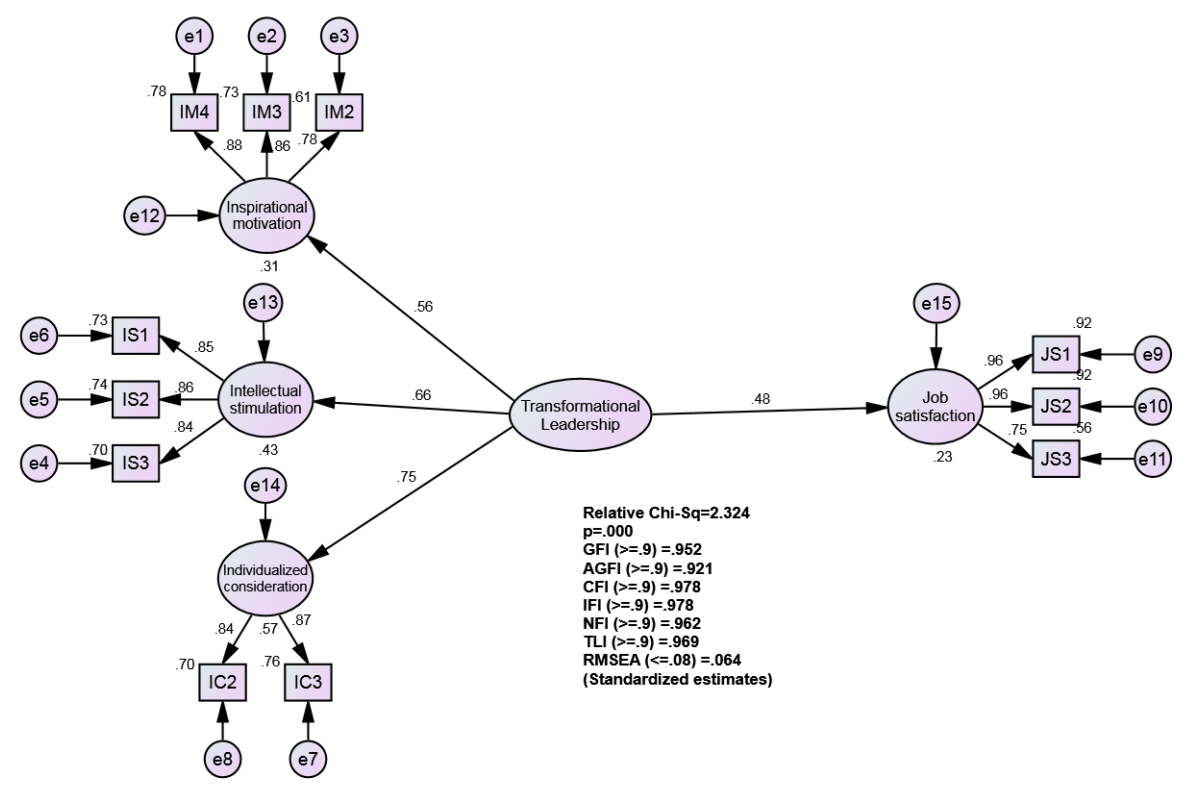

Figure 1: structural model of the study

Table 4: Regression estimates

\begin{tabular}{|c|c|c|c|c|c|}
\hline Relationship & $\begin{array}{c}\text { Standardized } \\
\text { estimate } \beta\end{array}$ & SE & $\begin{array}{c}\text { Critical } \\
\text { ratio }\end{array}$ & Probability & Results \\
\hline JS <--- TL & .478 & .112 & 5.941 & $* * *$ & Supported \\
\hline
\end{tabular}

\section{Discussion}

The purpose of this study to test the effect of TL on JS among academics staff. This objective has been achieved through the test the formulated hypothesis, the result indicated that TL has a positive and significant influences JS $(\beta=.478, \rho<0.001)$. This result suggests when academic staff regard their leaders(Head of departments) as more transformational they will be more satisfied with their jobs.TL transfer a sense of mission and intellectual stimulation Bass, (1985), it seems logical that perceived TL could intrinsically enhance more job satisfaction. to increase academics staff satisfaction, head of department at university should be able intellectually to challenge their academic staff and creatively solve problems. This finding is consistent with Munir et al., (2012) reported TL positively affect JS among academics staff and Conclusion the high quality of TL could increase employee job satisfaction. Similarly, An et al., (2019) TL positively related with job satisfaction. Obviously, academics staff were more satisfied with TL. Evidently The results support finding of previous studies, 
such as Eliyana, Ma'arif and Muzakki, (2019) TL has direct impact on JS. Puni, Mohammed and Asamoah, (2018) reported all the TL dimensions has a significant and interactive effect on JS. Abelha, Carneiro and Cavazotte, (2018); Singhry, (2018) confirmed the positive and significant relationship between TL and JS. on the other hand, result contrast with Thamrin, (2013) which found TL has nonsignificant impact on JS and conclude that TL cannot increase Job satisfaction among employees this study conducted among employee in a shipping company which may be different about academics staff perception. Furthermore, the result showed that individualized consideration has a stronger influence on JS ( $\beta=.75$ ), this support previous finding by Singhry, (2018), intellectual stimulation has positive affect on JS ( $\beta=.66$ ), similar result with Salau et al., (2018), inspirational motivation with ( $\beta=.56)$ same finding with Bayram and Dinç, (2015) found the IM significantly effect on JS in the education sector. Head of department as a leader should be more innovative when facing a problems and try to solve it by intellectual stimulation characteristic. However, Head of department should be more careful on academic staff supporting and enhance their self-development by individualized consideration characteristic. Furthermore, Head of department as a leader should hold a good role model in the creation of modern think and ideas and care about staff ideas and desires into consideration at the university decision-making process, Thus, could enhance and increase job satisfaction at universities among academic staff.

\section{Conclusion}

Leadership styles one of important element which neglected in developing countries in general and particularly in Iraq. the study reported TL components play important role in effecting job satisfaction among academic staff. Hence, leaders (head of department) are to deploy these components to increase and improve job satisfaction among followers. according the result TL has a significant impact on JS this result can send a message to universities to improve and enhance university leaders and could reduce the number of turnovers and increase the commitment among academics staff. however, satisfaction could positively effect on academics performance at university and enhance staff loyalty to their university and that will reflect on their productivity at workplace. also, the results showed there is a different impact between TL dimensions on JS, Individualized consideration with high impact on JS among academic staff this mean staff prefer the emotional support, modern learning chances and piece of advice and feedback from their leaders more than other components of TL this contrast with other results may because different context or different culture in Iraq. moreover, Leaders (head of department) should be involving the academic staff in decision making that will lead increase staff satisfaction and will positively reflect their performance and productivity.

the Theoretical implications, the study enriches the few kinds of the literature related in TL and JS in the context of Iraq and developing countries , the study has some limitations such as: first, a study conducted only in one university which cannot generalize the result on all the universities in Iraq. moreover, a study conducted in the private sector which may different environment within the public sector. second, sample size could be small. Future research should widely exam the impact of TL on JS among academics staff may be with more than one university and support these two dimensions with a mediator role.

\section{References}

Abelha, D. M., Carneiro, P. C. da C. and Cavazotte, F. de S. C. N. (2018) 'Transformational leadership and job satisfaction: Assessing the influence of organizational contextual factors and individual characteristics', Revista Brasileira de Gestao de Negocios, 20(4), pp. 516-532. doi: 10.7819/rbgn.v0i0.3949.

Ahmad, A. R. et al. (2013) 'The influence of leadership style on job satisfaction among nurses', Asian Social Science, 9(9), pp. 172-178. doi: 10.5539/ass.v9n9p172.

Ahmad, M. abdul aziz and Jameel, A. S. (2018) 'Factors Affecting on Job Satisfaction among Academic Staff', Polytechnic Journal, 8(2), pp. 119-128. doi: 10.25156/ptj.2018.8.2.161. 
Vision 2025: Education Excellence and Management of Innovations through Sustainable Economic Competitive Advantage

Alghamdi, M. G., Topp, R. and AlYami, M. S. (2018) 'The effect of gender on transformational leadership and job satisfaction among Saudi nurses', Journal of Advanced Nursing, 74(1), pp. 119127. doi: 10.1111/jan.13385.

Altunoğlu, A. E., Şahin, F. and Babacan, S. (2019) 'Transformational leadership, trust, and follower outcomes: a moderated mediation model', Management Research Review, 42(3), pp. 370-390. doi: 10.1108/MRR-01-2018-0036.

An, S. H. et al. (2019) 'Leadership and Job Satisfaction: Addressing Endogeneity With Panel Data From a Field Experiment', Review of Public Personnel Administration. doi: $10.1177 / 0734371 X 19839180$

Anjali, K. T. and Anand, D. (2015) 'Intellectual Stimulation and Job Commitment: A Study of IT Professionals', IUP Journal of Organizational Behaviour.

Antonakis, J., Avolio, B. J. and Sivasubramaniam, N. (2003) 'Context and leadership: An examination of the nine-factor full-range leadership theory using the Multifactor Leadership Questionnaire', Leadership Quarterly, pp. 261-295. doi: 10.1016/S1048-9843(03)00030-4.

Bass, B.M., 1985. Leadership: good, beter, best, organizationaldynamics. NY: Academy of Leadership.

Bass, B. M. (1997) 'Does the Transactional - Transformational Leadership Paradigm Transcend Organizational and National Boundaries?', American Psychologist. doi: 10.1037/0003-066X.52.2.130.

Bass, B.M., 2000. The future of leadership in learning organizations. Journal of leadership studies, 7(3), pp.18-40.

Bass, B. M. et al. (2003) 'Predicting unit performance by assessing transformational and transactional leadership', Journal of Applied Psychology. doi: 10.1037/0021-9010.88.2.207.

Bass, B. M. and Avolio, B. J. (1993) 'Spaef Transformational Leadership and Organizational Culture Transformational Leadership and Organizational Culture', Source: Public Administration Quarterly.

Bass, B. M. and Avolio, B. J. (2004) Multifactor Leadership Questionnaire, Manual and Sample Set, Mind Garden. doi: 10.1037/t03624-000.

Bass, B. M. and Riggio, R. E. (2005) Transformational leadership: Second edition, Transformational Leadership: Second Edition. doi: 10.4324/9781410617095.

Bayram, H. and Dinç, S. (2015) 'Role of Transformational Leadership on Employee's Job Satisfaction: the Case of Private Universities in Bosnia and Herzegovina', European Researcher, 93(4), pp. 270281. doi: 10.13187/er.2015.93.270

Burns, J. M. (1978) 'Leadership, 1978', Many translations and later editions. doi: 10.1007/978-4-43109429-6_20.

Byrne, B. M. (2001) 'Structural equation modeling with AMOS: Basic concepts, applications, and programming.

Mahwah, NJ: Lawrence Erlbaum Associates, Inc.', Structural equation modeling with AMOS: Basic concepts, applications, and programming, 1(1), pp. 55-86. Available at: http://kharazmistatistics.ir/Uploads/Public/MY article/Structural Equation Modeling With.pdf.

Chau, P. Y. K. (1997) 'Reexamining a model for evaluating information center success using a structural equation modeling approach', Decision Sciences, 28(2), pp. 309-334. doi: 10.1111/j.1540- 
Vision 2025: Education Excellence and Management of Innovations through Sustainable Economic Competitive Advantage

5915.1997.tb01313.x.

Chen, C. F. (2006) 'Job satisfaction, organizational commitment, and flight attendants' turnover intentions: A note', Journal of Air Transport Management. doi: 10.1016/j.jairtraman.2006.05.001.

Dappa, K., Bhatti, F. and Aljarah, A. (2019) 'A study on the effect of transformational leadership on job satisfaction: The role of gender, perceived organizational politics and perceived organizational commitment', Management Science Letters, 9, pp. 823-834. doi: 10.5267/j.msl.2019.3.006.

Eliyana, A., Ma' arif, S. and Muzakki (2019) 'Job satisfaction and organizational commitment effect in the transformational leadership towards employee performance', European Research on Management and Business Economics. AEDEM, pp. 1-7. doi: 10.1016/j.iedeen.2019.05.001.

Fornell, C. and Larcker, D. F. (1981) 'Evaluating Structural Equation Models with Unobservable Variables and Measurement Error', Journal of Chemical Information and Modeling. doi: 10.1017/CBO9781107415324.004.

Hair, J. F. et al. (2009) Multivariate data analysis: A global perspective, Multivariate Data Analysis: A Global Perspective. doi: 10.1016/j.ijpharm.2011.02.019.

Hanim, W. et al. (2018) 'Leadership Capability Framework for the Construction Industry Leaders in Malaysia', International Journal of Engineering \& Technology, 7, pp. 505-509.

Hu, L. T. and Bentler, P. M. (1999) 'Cutoff criteria for fit indexes in covariance structure analysis: Conventional criteria versus new alternatives', Structural Equation Modeling. doi: $10.1080 / 10705519909540118$.

Kline, R. (2010) Principles and practice of structural equation modeling, Structural Equation Modeling. doi: 10.1038/156278a0.

Jameel,A.S. and Ahmed,A.R.(2019). Leadership and Performance of Academic Staff in Developing Countries. In Proceedings of the 33rd International Business Information Management Association (IBIMA), ISBN: 978-0-9998551-2-6 , 10-11 April, 2019, Granada, Spain.

Locke, E. A. and Latham, G. P. (1990) 'Work Motivation and Satisfaction: Light at the End of the Tunnel', Psychological Science. doi: 10.1111/j.1467-9280.1990.tb00207.x.

Munir, R. I. S. et al. (2012) 'Relationship between Transformational Leadership and Employees' Job Satisfaction among the Academic Staff', Procedia - Social and Behavioral Sciences, 65(ICIBSoS), pp. 885-890. doi: 10.1016/j.sbspro.2012.11.215.

De Nobile, J. (2017) 'Organisational communication and its relationships with job satisfaction and organisational commitment of primary school staff in Western Australia', Educational Psychology. doi: 10.1080/01443410.2016.1165797.

Northouse, P. G. (2016) Leadership : theory and practice (7th. Edition), SAGE Publications. doi: $10.1517 / 14656566.2014 .852538$.

Puni, A., Mohammed, I. and Asamoah, E. (2018) 'Transformational leadership and job satisfaction: the moderating effect of contingent reward', Leadership and Organization Development Journal, 39(4), pp. 522-537. doi: 10.1108/LODJ-11-2017-0358.

Salau, O. et al. (2018) 'Integrated datasets on transformational leadership attributes and employee engagement: The moderating role of job satisfaction in the Fast Moving Consumer Goods (FMCG) industry', Data in Brief. Elsevier Inc., 19, pp. 2329-2335. doi: 10.1016/j.dib.2018.06.032. 
Vision 2025: Education Excellence and Management of Innovations through Sustainable Economic Competitive Advantage

Sharma, S. et al. (2005) 'A simulation study to investigate the use of cutoff values for assessing model fit in covariance structure models', Journal of Business Research, 58(7), pp. 935-943. doi: 10.1016/j.jbusres.2003.10.007.

Singhry, H. B. (2018) 'Perceptions of leader transformational justice and job satisfaction in public organizations', International Journal of Public Leadership. doi: 10.1108/ijpl-01-2018-0007.

Spector, P. E. (1985) 'Measurement of human service staff satisfaction: Development of the Job Satisfaction Survey', American Journal of Community Psychology. doi: 10.1007/BF00929796.

Spector, P.E. (1997), Job Satisfaction: Application, Assessment, Cause, and Consequences, Sage, Thousand Oaks, CA.

Thamrin, H. M. (2013) 'The Influence of Transformational Leadership andOrganizational Commitment on Job Satisfaction andEmployee Performance', International Journal of Innovation, Management and Technology, 3(5). doi: 10.7763/ijimt.2012.v3.299.

Torlak, N. G. and Kuzey, C. (2019) 'Leadership, job satisfaction and performance links in private education institutes of Pakistan', International Journal of Productivity and Performance Management, 68(2), pp. 276-295. doi: 10.1108/IJPPM-05-2018-0182.

Wan Omar, W. A. and Hussin, F. (2013) 'Transformational Leadership Style and Job Satisfaction Relationship: A Study of Structural Equation Modeling (SEM)', International Journal of Academic Research in Business and Social Sciences. doi: 10.1016/j.devcel.2015.11.014. 